\title{
Review of Semiotic Landscapes: Language, Image, Space by Adam Jaworski and Grispin Thurlow
}

\author{
Felix Banda \\ Linguistics Department, University of the Western Cape
}

\begin{abstract}
lthough the volume was published

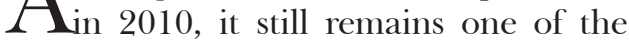
most important contributions to a new field of enquiry in the study of language and signage in public spaces initially conceptualised and institutionalised by Landry and Bourhis (1997) as linguistic landscapes (LL). They defined linguistic landscapes as "[t]he language of public road signs, advertising billboards, street names, place names, commercial shop signs, and public signs on government buildings combine to form the linguistic landscape of a given territory, region, or urban agglomeration" (p. 25). As the title of the volume suggests, the aim was to extend the study to consider other semiotic material in place rather than linguistic ones alone. Jaworski and Thurlow prefer the term semiotic landscapes to LL to account for the fact that descriptions of space are not just about language, image and space, but more so about how interlocutors engage with semiotic material including objects in place.
\end{abstract}

The volume has an introduction by the two editors followed by 13 chapters covering a range of topics and contributions by some of the major scholars in linguistic/semiotic landscapes studies.

The introduction by Jaworski and Thurlow introduces semiotic landscapes as a new area of enquiry, focusing on the interaction between language, image and space-especially how culture and textual mediation are implicated in the discursive and multimodal construction of space. In setting the background, the editors make it clear within a few paragraphs that the aim was to try to extend the conceptualisation of landscapes beyond what was premised in Landry and Bourhis (1997) and other earlier studies, which had focused on often out-of-context survey and questionnaire data. Their interest is the intersection of visual discourse, language and sociocultural aspects of spatial practices. As also seen from the title, the volume owes much to Kress and Van Leuwen's (2006) notion of multimodality in which language is just one of many semiotic modes used for representation and communication. Additionally, they draw on Scollon and Scollon's (2003) geosemiotics and Harvey's (2006) dynamic conceptualization of space as a consequence of human interaction practice-that is, space is invented through human interactions with signs in place. 
Jaworski and Thurlow are critical of LL studies and a number of stances put forward in such scholarship, including the predominantly quantitative and survey based data. Ironically, Jaworski and Thurlow acknowledge that the majority of chapters in the volume are on LL, that is, written language in place rather semiotic landscapes as proposed in their introduction. They propose a more genre- and context-specific study of language in the landscape of texts. On the whole the introduction gives an excellent assessment of LL studies and offers directions including relevant literature for the study of semiotic landscapes.

Chapter 1, written by Jeffery Kallen, takes issue with the 'top-down' versus 'bottom-up' dichotomy often made in earlier LL studies such as Ben-Rafael et al. (2006). He notes that official and non-oficial languages/signage are not neccessaily hierachical as they operate in different domains or parallel universes. Using data from Dublin's semiotic landscapes, Kallen goes on to suggest five (which he extends to seven) spatial frameworks in which to analyse signage: civic, marketplace, portals, walls and detritus zones (and also community and the school). These, he argues, constitute the complementary systems or domains in which to consume signage. He concludes that, although one finds many bilingual English-Irish signs, the landscapes are dominated by English. However, one also finds signage in Polish, Chinese and French, which he attributes to immigration, international tourism and business.

Mark Sebba contributes the second chapter, which looks at 'mobile' public texts as found on banknotes, pamphlets, tickets, vehicles, and so on. He suggests that both fixed and 'unfixed' signage need to be analysed in the same way as kinds of discourse in context. Second, using the dominance of Afrikaans and English in the apartheid South Africa's landscapes, Sebba argues that the white population erased African languages from public spaces. This ideological and social engineering of space was designed to prop up Afrikaans as being equal in status to English. The reality, however, was that whereas Afrikaans had more status in rural areas, English remained the language of status in business circles and urban areas. Third, the ideological project of making English and Afrikaans visible had little impact on the linguistic diversity on the ground where various African languages continued to be spoken.

In chapter 3, Nikolas Coupland argues that the presence of Welsh in Wales' LL reflects an idealised political and ideological perspective of 'true bilingualism' rather than 'any objective realities of bilingual usage' (p. 79). He then concludes that the bilingual signage reflect the 'top-down' aspect of language planning in Wales.

In an interesting contribution, Susan Dray's chapter 4 explores the use of non-standard language in the semiotic landscapes of Jamaica. Dray's focus is the interplay and influence of Jamaican creole on the national landscapes. From the outset it is clear that what constitutes standard and non-standard English in the Jamaican contexts is not always clear-cut. She gives an example of official government signage often re-appropriating what could be considered non-standard forms of English (such as 'Walk good') in some of its messages. Even Dray's linguistics students considered 'Walk good' a standard Jamaican English form. Reminiscent of what Stroud and Mpendukana (2009, 2010) have called signs of neccessity, Dray finds a lot of innovation and resourcefulness in Jamaicans' re-using of materials such as corrugated zinc doors 
for signage. As Dray correctly notes, the use of repurposed material (Bolter and Grusin 2000) should not be seen as a sign of lack of authority; rather it reflects the resourcefulness which is commonplace in Jamaica and indeed Africa. Although standard English and Jamaican creole remain in hegemonic existence, the latter is increasingly gaining visual presence in the visual public domains so that there are times when the non-standard form is seen as the legitimate and preferred code. In essence, standard English and Jamaican creole represent the different and complementary identity options available to Jamaicans.

Chapter 5 is about what Ingrid Piller describes as the sexualisation of travel-related public spaces in Basel, Switzerland. Drawing data from shop fronts, local newspaper adverts, websites selling 'prostitutes', nightclubs and escort services, Piller explores the intersection between the semiotics of the sex industry and the semiotics of Swiss tourism. She shows that high levels of mobility are connected to high visibility of the sex industry, which also linked to high quality and multilingual construction of the upper class Swiss national identity.

Alastair Pennycook contributes chapter 6 , in which he characterises graffiti as integral to semiotic landscapes in cityscapes. Pennycook introduces several notions drawn from a number of disciplines, which would be useful to theorising and studying semiotic landscapes. Some of the concepts are graffscapes (graffiti in space), gaze, 'walk-in' navigation of space, urban cityscapes, counter-literacies and cultural flows. He also characterises semiotic landscapes in terms of spatial narrations. Drawing on Cannadine(2000:8), Pennycook contributes a different way of conceiving space when he argues that people reshape the environment during landscaping. He also argues that semiotic landscaping is a conscious act and that space is always under construction, so that it is invented. In a way, Pennycook's contribution appears to extend the scope of semiotic landscapes beyond what Jaworski and Thurlow proposed in the introduction. In arguing for narration of place, Pennycook expands the 'scenery' to include environmental material (trees, grass, mounds, etc.) and/or how these are reused in the reshaping of place.

This is followed by a chapter by Rodney H. Jones who investigates the different ways teenagers use computers at school and home in Hong Kong. His interest is in the differential effect computers have in governing how students orient themselves in these spaces and toward other people in the vicinity. He notes that in the home, the students' computer use or discourse in place included conversations with familiy and related to activities taking place in the environment. Magazines, newspapers and other objects often attract the gaze. Whereas in the home the orientation was polyfocal, students' orientation in the school environment tended towards being monofocal as a result of schoolbased literacy practices reinforced by the panopticon style setting (Foucault 1977) of a traditional classroom in which students sit at 'long tables arranged in rows...' (p. 160).

Chapter 8 by Thomas Mitchell looks at how a newspaper article in the Pittsburgh Post-Gazette was framed in such a manner so as to put a wedge between new Latino immigrants and established 'traditional' inhabitants of Beechview. Mitchell finds that the article did this through exploiting common metaphors of Othering: immigration as an 'invasion' and as a 'flood'. He contends that the presence of Spanish in the semiotic landscapes may have contributed to the newspaper exaggerating the actual number of immigrants living in Beechview. 
Chapter 9 by Thurlow and Jaworski draws on the idea of elite closure, to show how silence as a discursive and social construct is used as semiotic resource in high-end adverts and as a marker of luxury and social status in commercial representations of social space. They see what they call an 'anti-communicational' ethos or commodification of silence in luxury tourism adverts as encoding an elitist ideology of 'segregation and isolationism' (p. 212).

In chapter 10, Abousnnouga and Machin problematises war monuments as semiotic resources on which government legitimise discourses of nation, nationalism and the virtues of militerism. In turn, they use multimodal discourse analysis to show how the English/British government continues erecting new war monuments while sprucing up old ones with new names of ('forgotten') 'fallen' soldiers, to disseminate certain values, identities, goals and politically-driven motives.

Continuing with the theme of monuments, Shohamy and Waksman (chapter 11) characterise monuments as ideological sites of discourses of nation and nationalism, and as places of tourism and immigration. They focus on the Ha'apala monument in the city of Tel Aviv, which has become a place in which texts and discourses of the Jewish ideology and nationhood are produced and consumed. The place has also become a site of ownership of space and redefinition of Others, reinforcement of collective identity, shared traumatic past and a site for a shared future recruitment of the private for the public.

In chapter 12, Gendelman and Aiello look at façades as semiotic resources in global capitalism. Their interest is in how city spaces and infrastructure are deployed as media of communication in the global marketplace. In this idiom, buildings become semiotic artfacts/ material resources for tourism guidebooks, brochures, t-shirts, etc. They conclude that, although the post-Soviet era façades reflect the commodified local identity, they also depict the materialities of both pre- and post-Soviet façades. Through notions of layering and referencing, they demonstrate that the very act of 'renovation' is counterbalanced by ideals of preservation of the 'original' appearance.

The last chapter is contributed by Ella Chmielewska who looks at the visual sphere, that is, the material objects of semiosis to highlight the potential of close reading of discreet place-scapes as a way of emphasising the challenges of placing visual material in positions traditionally reserved for written language. She jettisons multimodality and opts for a wider socio-cultural theory to show that the semiotic materials in place are the resources for the consumption and production of cityspace, both of which require subjective 'reading' and appreciation of meanings.

The volume is generally well edited with chapters neatly flowing into each other. As indicated earlier, Jaworski and Thurlow are the first to acknowledge that most of the chapters in the volume do not adhere to the methodologies and analytical/theoreotical ethos being propulgated by the editors. In essence, they also follow the path of LL studies that they criticise. Another area of concern is that the chapters are mostly about urban areas, which means vast amounts of rural and countryside are left out. These concerns are also raised in a recent special issue of linguistic/ semiotic landscapes of the Journal of Sociolinguistics, edited by Zabrodskaja and Milani (2014). Zabrodskaja and Milani (2014) note that despite researchers such as Stroud and Mpendukana (2009, 2010), Blommaert and Huang (2010), Shohamy and Gorter (2009), Pennycook 
(2009, 2010) and Jaworski and Thurlow (2010) to name a few, who have all suggested an 'expansion of the scenery' this is slow to happen. Recent work on linguistic/semiotic landscape studies has been moving in circles, shifting from qualitative analysis and right back to quantitative analysis. Thus, studies have continued focusing on written language (sometimes exclusively) rather than in conjuction with other semiotic landscapes and people's experiences and interactions in these spaces.

The volume is an excellent contribution, whether one chooses to go the traditional route of LL studies with its focus on surveys and questionnaire data and/or the more recent material ethnographies and semiotic landscape route.

\section{REFERENCES}

Adam Jaworski and Crispin Thurlow. 2010. Semiotic Landscapes: Language, Image, Space. London and New York: Continuum.

Ben Rafael, Elena Shohamy, Muhammad Hassan Amara and Nira Trumper-Hecht. 2006. Linguistic landscape as symbolic construction of the public space: The case of Israel. In Durk Gorter (ed.) Linguistic landscape: A new approach to multilingualism. Clevedon: Multilingual Matters. 7-30.

Blommaert, Jan and April Huang. 2010. Semiotic and spatial scope: Towards a materialist semiotics. Working papers in urban language E literacies 62. Tilburg: Tilburg University.

Bolter, J. David and Richard Grusin. 2000. Remediation: Understanding new media. Cambridge: MIT Press.

Cannadine, David. 2000. Class in Britain. London: Penguin.

Cenoz, Jasone and Durk Gorter. 2006. Linguistic landscape and minority languages. International Journal of Multilingualism 3: 67-80.
Kress, Gunther and Theo Van Leeuwen. 2006. Reading images: The grammar of visual design. London: Routledge.

Landry, Rodrigue and Richard Y. Bourhis. 1997. Linguistic landscape and ethnolinguistic vitality: An empirical study. Journal of Language and Social Psychology 16 (1): 23-49.

Pennycook, Alistair. 2009. Linguistic landscapes and transgressive Semiotics of graffiti. In Shohamy, Elana \& Durk Gorter (eds.). Linguistic landscape: Expanding the scenery. New York: Routledge. 302-312.

Pennycook, Alistair. 2010. Spatial narrations. In Jaworski, Adam and Crispin Thurlow (eds.). Semiotic landscapes: Language, image, space. London: Continuum. 137-150.

Prior, Paul and Julie Hengst. 2010. Introduction. Exploring semiotic remediation as discourse practice. Houndmills: Palgrave.

Scollon, Ron and Suzanne Wong Scollon. 2003. Discourse in place: Language in the material world. London: Routledge.

Schama, Simon. 1995. Landscape and memory. New York: Alfred Knof.

Shohamy, Elena and Durk Gorter (eds.). 2009. Introduction. Linguistic landscape: Expanding the scenery. New York: Routledge.

Stroud, Christopher and Sibonile Mpendukana. 2009. Towards a material ethnography of linguistic landscape: Multilingualism, mobility and space in a South African township. Journal of Sociolinguistics 13 (3): 363-386.

Stroud, Christopher and Sibonile Mpendukana. 2010. Multilingual signage: A multimodal approach to discourse of consumption in a South African township. Social Semiotics 20 (5): 469-493.

Zabrodskaja, Anastassia and Tommaso M. Milani. 2014. Signs in context: Multilingual and multimodal texts in semiotic space. Journal of Sociolinguistics 228: 1-6. 